\title{
ANALYSIS OF IMPLEMENTATION OF THE GOOD CORPORATE GOVERNANCE PT. BANK BNI SYARIAH BRANCH OF TASIKMALAYA
}

\author{
Setiawan Bin Lahuri \\ Lecture Magister Program \\ Department of Islamic Economic and Law-Sharia Faculty \\ University of Darussalam Gontor Ponorogo \\ Email: binlahuri@gmail.com \\ Vina Fithriana Wibisono \\ Student of Magister Program \\ Department of Islamic Economic and Law-Sharia Faculty \\ University of Darussalam Gontor Ponorogo \\ Email: vina.fithriana.wibisono@gmail.com
}

\begin{abstract}
PT. Bank BNI Syariah is one of the best Islamic bank, which obtained the best award as the most efficient bank and first ranked in the category of best good corporate governance report. So, this study aim to explore the extent of implementation good corporate governance in PT. Bank Syariah Branch Tasikmalaya. This study is a field research using inductive method and content analysis approach. Data collection is using primary and secondary data by observations, interviews, and documentation. The results indicate that PT. Bank Syariah Branch Tasikmalaya has implemented good corporate governance principle by well according the Islamic perspective. Described about it that bank has implemented "anti graft" accordance with al-Amanah\}-alJama > 'ah\}-al-Hasanah\} as a slogan in doing work; al-Tawhi>d and al-Rid\}a as the basis for forming personal caracter; every Dhuhur and Ashar prayer, the office is temporarily closed; Tarhib Ramadhan as routine program every June 19 by holding an MHQ competition.

Keyword: Good Corporate Governance, Islamic Corporate Governance, Sharia Banking.
\end{abstract}

\section{INTRODUCTION}

Good Corporate Governance is a one of success solution toward corporate its for growing up and beneficially in long time and all at once of it (Daniri, 2005). Because, bank is like a heart and machine on activator of economy it is a state must implement good corporate governance principle. William A. Lovette said;

"Bank and financial institution collect money and deposit from all elements of society and invest these fund in loans, securities and various other production assets". (Lovette, 1997; Nasution, 2007).

The development of good corporate governance has been started for long time ago in line the establishment of Corporate System (Muladi, dkk, 1991) in United Kingdom and United State of America (USA) around the18th century. The 
term of Good Corporate Governance (GCG) was first at corporate governance introduced in 1992 within the report came to be called Cadbury Report. This report has been prescriptived the worldview. As Cadbury Committe in Tjager, interprets about Corporate Governance is:

"A set of rules that define the relantionship between stakeholder, managers, creditors, the government, employees and other internal and external stakeholder in their right and responsibilities." (Tjager, et. All, KNKG, 2003).

Good Corporate Governance means of Regulation of Inonesian Bank (PBI) legal requirement on Leg No. 1, Number 6 Acc. Good Corporate Governance No. 8/4/PBI/2006, Good Corporate Governance is a good managerial system which apply prinsiples of transparency, accountability, independency, respnsibility, and fairness.

Therefore, sharia bank is an institution of business which operated by the intention is not only Islamic principles profit oriented but also on social oriented. As an institutional business for sharia banking must be directed for promoting in the al-Fala@h. (Rastuti,2015).

PT. Bank BNI Syariah is a banking institution in Indonesia. The bank was originally named the Syariah Business Unit of Bank Negara Indonesia, a subsidiary of PT. Bank BNI Persero, Tbk. Since 2010, the PT. Bank BNI Syariah Business Unit has been transformed into a sharia commercial bank under the name of PT. Bank BNI Syariah (www.bnisyariah.co.id, 2016). PT. Bank BNI Syariah is one of the best Sharia Bank, that obtain best reward such as Most Efficient Bank at 2016 and one of first ranking in best category of Good Corporate Governance (GCG) in Indonesia at 2016. (www.bnisyariah.co.id, 2016). The following data can be raised:

Table 1. Income Data of PT. Bank BNI Syariah

\begin{tabular}{lc}
\multicolumn{1}{c}{ Category of Income } & Total \\
\hline Dominant Customer & $52,96 \%$ \\
Financing & \\
Prouctive Financing & $22,78 \%$ \\
Commercial Financing & $16,38 \%$ \\
Micro Finance & $5,77 \%$ \\
Hasanah Card & $2,11 \%$ \\
\hline \multicolumn{2}{c}{ Total Income } \\
\multicolumn{2}{c}{ Source: www.bnisyariah.com }
\end{tabular}


Baseds on the background described above, this paper, thus, aims to explore the concept of Good Corporate Governance in Islamic Banking and to explore the implementation of Good Corporate Governance according with Islamic perspective in PT. BNI Syariah Branch of Tasikmalaya.

\section{THEORITICAL FRAMEWORK}

\section{Good Corporate Governance}

\section{Definition of Good Corporate Governance}

Generally, the definition of corporate governance can be divided into two senses. Firstly, in narrower sence corporate governance can be difined as a formal system of accountability of senior management to the stakeholders (Shleifer, dkk, 1997). Secondly, in expensive term, corporate governance includes the entire network of formal and informal relations involving the corporate sector and their consequences for society in general (Mesnooh, 2002; Salacuse, 2003).

The meaning of Corporate Governance followed in FCGI (Forum Corporate Governance in Indonesia) is the equipment regulations to organize a connection related the heels and the duties from Shareholder, Board of Commissioners, Board of Directors, Internal and External Audit, Committee Audit, Compliance Officer, Corporate Secretary, Sharia Supervisory Boards, and other stakeholders.

Organization of Economic Coorporation and Development (OECD) have been taked the definition from European Central Bank (ECB) gives the definition of governance as:

"Procedures and processes according to which an organization is directed and controlled. The corporate governance structure specifies the distribution of rights and resonsibilities among the different articipants in the organisation - such as the boards, managers, shareholders and other stakeholders - and lays down the rules and produsers for dicision - making.".(European Central Bank, 2004; Frankfurt: 2005). 


\section{Rules of Corporate Governance}

\section{1) The Anglo-Saxon Model}

The Anglo-Saxen model of corporate governance which is also known as market-based systems or shareholder-value system or principleagent model is considered as the most dominant theory championed by the Unite States and the United Kingdom. Market-based system of the United Kingdom and the United States are characterizted by arm's length relationship between corporations and investors who are said to be concerned primarily about short-term returns (Frank, dkk, 2004).

\section{2) The European Model}

Since the publication of Berle and Means, many have believed that there are significant problems with the Anglo-Saxon model. Another approuch of corporate governance was introduced known as the stakeholders or the European model. In this system, companies raise most of their external finance from banks that have close, long term relationships with their corporate customers (Berle, dkk, 1932).

\section{Principles of Good Corporate Governance}

\section{1) Transparency}

Transparency are containing of disclore element and equipping the information in a be on time manner, be equal to, clear, accurate, and comparable as well as accessible by importance fuctionary and society. Transparency was needful in order that in bank to carry out its business by objectively, profesionality and protect againts of interest for consumers (KNKG, 2012).

\section{2) Accountability}

Accountability are containing of element is function of clarity in the organization and manner his account for justify. Bank as institutional and fuctionary be possessed of his workly on transparent and accountable a 
scale. For it bank must be healty managament, measurable, and professional by keeping eye open the importance of shareholders, customer, and other manager. Accountability is the constitute prerequisite of necessary to work continously (KNKG, 2012).

\section{a. Responsibility}

Responsibility is containing of element to pursuence about regulation of legislation and internal certainly bank and also had charge of bank for society and his area. Its principle needful so as to assure had been protected of continuity the business in long time and gotten confession as good corporate citizen (KNKG, 2012).

\section{b. Independency}

Independency is containing the element of autonomy or stand alone from another side and objectivities his the work and the duty. In the connection from independency principle, bank must be managed independently in order to organize corporate of as well as entire under the row another to domina and can not be considered actions by either party can be influencing the objectivity and professionalism in perform of duties and responsibility (KNKG, 2012).

\section{c. Fairness}

Fairness is continuing of element is substance fair treatment and also the same way as opportunity in that portion. In this management, bank must always to observe the importance of shareholder, consumer and other manager based on fairness principle from each side (KNKG, 2012).

\section{Purposes and Element of Good Corporate Governance}

According from Mr. Wolfenshon, World Bank President, have been summarized that the purpose of the good corporate governance is to incarnating the justice, transparency and accuntability (www.encycogov.com, 2011). So, can be said that the porpuse of good corporate governance is incarnating the justice for all stakeholders by means of the creation of transparency and accountability be even greater or bigge. The justice for stakeholders also can heed with the value raising is natural on his participation. 
The elements of good corporate governance is coming inside the company and outside the company. That elements always needful inside the company namely is Corporate Governance-Internal. The elements is coming from inside company is (1) Shareholders; (2) The Board of Director; (3) The Board of Comisioner; (4) Managers, (5) The employees, (6) Remunerasi systems of job-based, (7) Audit committee. Whereas the elements always be needful inside the company inter aila is (1) Openness and confidentiality; (2) Transparency; (3) Accountability; (4) Fairness; (5) A rule from code of conduct (Sutedi, 2010).

Further, Sutedi did explain that the elements is coming from outside company and the elements always be needful outside beside to be Corporate Governance-Eksternal. The elements is coming from outside the company is (1) Sufficiency by-law and sets of law equipment; (2) The investors; (3) The institute of information providers; (4) Public accountan; the institute had taken side public interest, not be group; (5) Lender or loaner; (6) The institute are legaizing. The elements always be needful outside the company include by (1) A rule from code of conduct; (2) Fairness; (3) Accountability; (4) Law guarantic (Sutedi, 2010).

\section{Islamic Good Corporate Governance Principles of Islamic Corporate Governance 1) al-Tawhi>d and al-Shu>ra Based Approach}

As the foundation of Islamic faith is al-Tawhi>d (Al-Faruqi, 1982), the basis for the corporate governance framework also emanates from this concept. Allah says in Al-Qur'an:

"Men who celebrate the praises of Allah standing, sitting, and lying down or theis sides, and contemplate the wonders of creation in the heavens and the earth, (with the thought): "Our Lord! Not for naught Hast thought created all this! Glory to Thee! Give us Salvation from the penalty of the Fire” (QS. Al-Imran: 191).

This verse provides fundamental principles of governance where everything created by Allah has a porpose and human being is created to be the world's vicegerent. By putting a trust to mankind as a vicegerent, Allah plays actively roles to monitor and involve in every affairs of 
human being and he is aware and knowing everyting all the times (Chapra, 1992).

\section{2) Dimension of Islamic Corporate Governance}

The main dimension of Islamic Corporate Governance based on Schieffer et al. citation by Wael Moustafa Hassan, that is (Schieffer, dkk, 2008):

a. al-'Adl: (Justice) represents equilibrium and fairness in every action in the life like passing judgments, responsibilities toward others, protecting society members' rights regardless of their religion, sex and nationalities. It's a comprehensive framework for the overall society including individuals and institutions which considered as cornerstone for Islamic values.

b. Al-H\}isbah\}: It's an Islamic system in which the state has the right to inspect all practices in the market to ensure fairness and equity. These procedures may be extended to deeply inspect minor crimes in the society in this sytem the state recruit inspector or supervisor or what so called al-Muh\}tasib.

c. Self-Consciousness/ mindfulness (alertness): Schieffer et all, stated that "Islam puts strong emphasison the conscious recognition of the interdependence between the incisible and the visible, whereby the invisible is regarded as the cause of the visible ("software leads hardware"). Hence, good corporate governance start on the psychological level of the individual."

d. al-Tawhi>d: Connectivenesess ("unity"), As per Islamic literature there are three levels of unity. Unity of humanity, Unity of the People of Book and Unity of Muslims. This concept should be applied on all parties within the organization.

e. $\boldsymbol{a l}$-S $\boldsymbol{u} \boldsymbol{u}>\boldsymbol{r a}>$ : Consultancy - One of the main concept in Islam in $a l$ $S\} u>r a>$ (consultancy) this mean that the decision making process should be done through consultancy and not based on dictatorial ations. 
According to Muqorobin, there are four basic of the caring out the corporate governance in Islamic perspecrive is al-Tawhi>d, al-Taqwa> and al-Rid\}a>, equilibrium, and al-Mas\}lah\}ah\}, are fourth basis it explainable as follow (Muqorrobin, 2017):

a. al-Tawhi>d: Tauhid is highest principality from all the activity of life Islamic human being and become hand-grip each al-muslim without dicriminated of $a l-M a z \mid h a b$ (ideology), or an other ideology his attentive. This principle are teach for human being always be remember if his self have been only God creature must at up to God Allah and bring about the rule and leave his prohibition.

b. al-Taqwa> and al-Rid\}a>: al-Taqwa> and al-Rid\}a> is became of prominent principal his upright a Islamic institute into anyting type about basis of al-Taqwa> to God Allah and his al-Rid\}a>. Business corporate governance in Islam also must upright on the top the foundation of taqwa to God Allah and his al-Rid\}a>.

c. Equilibrium (al-Tawa>zun) or Justice (al-Mi>za>n): is these two concept about equilibrium in Islam. Desribing a al-Tawhi>d in context of social in societies included in business and economic.

d. al-Mas\}lah\}ah\} (prosperity): Maintenance of leadership authority and religiousness in order to keep physical or social harmonism, be intended also to fill the purpose has applicable Islamic sharia (alMaqas\}idu-al-Shari> 'ah), it is have achieved maslahah for human being in total as shape from islamic desire became rahmat for universe.

\section{The Differences Corporate Governance between Non-Islamic and Islamic}

The contrast between the mainstream and Islamic features of corporate governance is exemplified in scheme 3.3.1The important point tonote in this scheme is that huma resource development, preference formation and consequent managment, employees and shareholders in mainstream corporate governance perspectives are driven by the objective. 


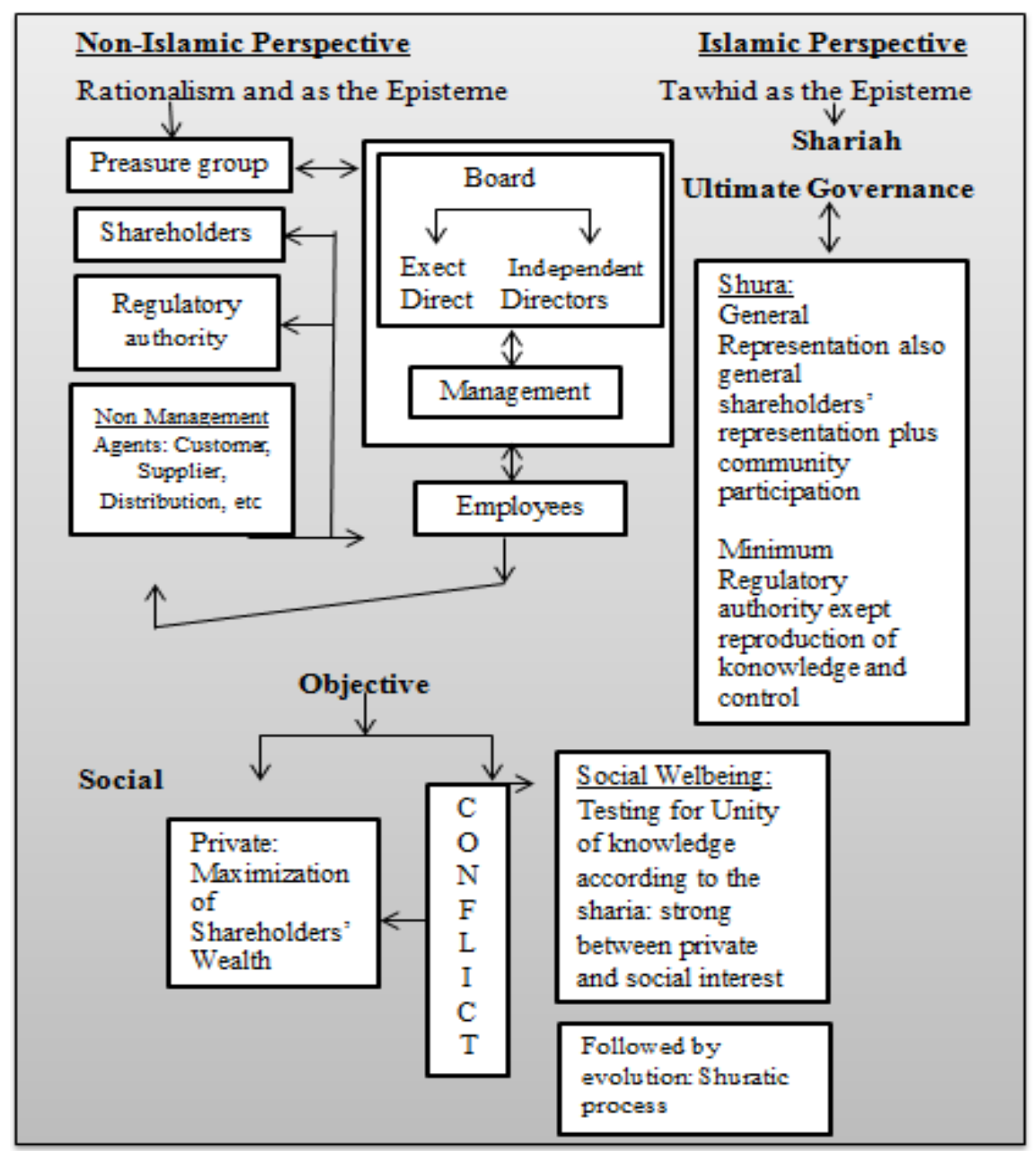

Figure 1. Comparative views of Corporate Governance: Islam and the other perspective Sourch: (Masadul Alam Choudhury and M. Ziaul Haque), Corporate Governance in Islamic Perspective, (Corporate Governance Jurnal), 2006.

\section{METHODOLOGY}

This research This type of research is including in field research has the quality for using content analysis. Field research is obeservation method of research directly conduct observation to obtain information needed in preparation of final project report. Location of the research was conducted at PT. Bank BNI Syariah branch of Tasikmalaya which is addreassable at Jl. Masjid Agung no. 26, Block of Kaum Kaler, Kelurahan Tawangsari, Kecamatan Tawang, Tasikmalaya, West Java, Indonesia.

This research will be done by using materials as endorser for complited this study by primary and secondary data. The primary data, a source of data obtained occurred (Prastowo, 2012). And primary data obtainable by bringing about result of research from field collecting at the obsevation, interview and documentary and 
would involve with composed of Bank Manager, either or the other side of the shield who is interested parties with the object's research for acquiring relevanly data in aim of research to bank research (on one's side in PT. Bank BNI Syariah branch of Tasikmalaya on 2016). Secondary research data is data collected from a second hand or from other sources which had been available before the study is done. And secondary data obtainable by bringing about relevant technical or do ducumentary of related dependent notes for publishing statement of object research.

Data and information will be done for this research collectable by using three methods, by (Sugiyono, 2011):

a. Observation

Observation is often reffered to as a method of observation. In short the method of observation is a systematic meticulous way. Or a careful and systematic observation and recording of the phenomena under investigation.

b. Interview

Interview method is a research method to guide the interview asking questions, listening to answers, observing and recording the behavior of all the responses from surveyed.

c. Documentation

Document is a past event that written or printed form of anecdotal records, letters, diaries, and document, in this case could include internal sheet, comunication to the public of diverse, files, program descriptions.

Data analysis will be done using by inductive method. This form of inductive method is paragraphs that are preserved by explaning specific issues (containing evidences) which end with a general statement of conclusions or methods with a special to public approuch (going from specific to the general (http://rismarhaesa15.wordpress.com).

\section{RESULT AND DISCUSSION}

\section{The Implementation of Good Corporate Governance in PT. Bank BNI Syariah}

Actually, the implementation of good corporate governance in PT. Bank BNI Syariah branch of Tasikmalaya can be said that the employees there when first enter and work directly there is quite difficult (Dwi, 2017). 
The meaning of quite difficult is because that time until now, that PT. Bank BNI Syariah branch of Tasikmalaya requires employees who are tough, strong and willing to work hard and also has a working slogan that "Avoids or Rejects of Gratification in any Performance whatsoever". Because, in the upbringing of he irect manager that is planting Islamic values with the not "Working is worship, not seeing from the salary earned, doing with sincercity to get al-Rid\}a $>$ from Allah and also to get salary must be oriented" do not look in terms of salary earned but must see the worship also.

Then, PT. BNI Syariah branch of Tasikmalaya got the award of good corporate governance rank. That, between the implementation of good corporate governance in PT. Bank BNI Syariah at branches with the center is not too far away. Precisely, PT. Bank BNI Syariah at braches always communicate and still synergize with the center, because if something happens or constaints in the PT. Bank BNI Syariah at branches then most report immediately to PT. Bank BNI Syariah at center.

\section{The Implementation of Five Pillar of Good Corporate Governance in PT. Bank BNI Syariah Branch of Tasikmalaya}

1) Transparency

In daily activities of the implementation on tansparency principle here is "No push the gratification or not receiving any compensation from anyone". Because, in the case of related to some third parties in the work, can bringing us to faults rules. The employees must take the supplying of commodity of couse so done confersation with third parties such as vendors. That casually was given to employees some the retaine.

\section{2) Accountability}

The result from accountability here is all the constraint with stakeholders are fine. However, for general of job standardization to stakeholders must follow from the Cetral PT. Bank BNI Syariah.

\section{3) Responsibility}

The responsibilities had done is bend cuve about table office recervation to stakeholders/ vendors. Authomatic the table must also bestandar must be equal to cenral standard. With that, they already understand before we explain.

\section{4) Independency/Professional}

Implementation of independent principle in BNI Syariah branch of 
Tasikmalaya is have the concept "al-Ama>nah\}-al-Jama>'ah" is the guide to work well and prioritize the intention of worship which usually read every day "Monday and Wednesday" to all member, that is call as "Morning Breaving” will be done before $08.00 \mathrm{am}$.

Corporate culture of BNI Syariah is formulated by exploring the values that are believed by all human employees as superior values to support the vision, mission and targets of thecompany, namely integrity, sence of business, focus on quality and customer satisfaction which set fourth in the corporate values of "al-Ama>nah\}-al-Jama>'ah-alHasanah". Scheme for that ilustrasion is bellow:

Table 2. Corporate Values of PT. Bank BNI Syariah

\begin{tabular}{|c|c|}
\hline \multirow{5}{*}{ Amanah } & Honest and fulfilling promises \\
\hline & Responsible \\
\hline & Dedicated to deliver best performance \\
\hline & Sincerely working and promiting worship goodwill \\
\hline & Serving exceeds the expectation. \\
\hline \multirow{5}{*}{$\begin{array}{l}\text { al- } \\
\text { Jama'ah }\end{array}$} & Caring and daring to give and receive constructive feedback \\
\hline & Building a professional synergy \\
\hline & Sharing useful knowledge \\
\hline & Understanding the relationshipof work processes \\
\hline & Strengthening effective leadership \\
\hline $\begin{array}{c}\text { al- } \\
\text { Hasanah }\end{array}$ & $\begin{array}{l}\text { Is the Corporate Value of PT. Bank BNI Syariah which becomes } \\
\text { the main character for employees and the Company which makes } \\
\text { PT. Bank BNI Syariah distinctive and easily recognized. }\end{array}$ \\
\hline
\end{tabular}

The culture of "al-Ama>naht-al-Jama> 'ah" is supported by there three cultural pillars; (1) risk \& complience, (2) performance, and (3) service.

Table 3. Cultivate Amanah and Jamaah To Create Hasanah Individuals

\section{Pillar Risk \& Compliance}

-Is the basis in working by upholding compliance atitute towards the sharia principle and regulations and always work with the prudent principle to obtain quality results.

\section{Pillar Performance}

-Is the basis in working by upholding continuous improvement attitude to achieve optimal results. 
-Is the basis in working by upholding serving exceeds the expectation attitude

\section{5) Fairness and Equality}

BNI Syariah branch of Tasikmalaya was implementing fairness principles in "Cash ration policy or benefit cost ratio (profit sharing) for customers". The example in distribution of cash ration policy or benefit cost ratio on mudharabah is for the customer (12\%), that his profit sharing had been given cotton with DPS (Sharia Supervisory Board).

\section{The Implementation of Islamic Corporate Governance in PT. Bank BNI Syariah branch of Tasikmalaya}

According to the concept of Islamic perspective of good corporate governance's princple in PT. Bank BNI Syariah branch of Tasikmalaya is made of al-Tawhi>d\} and al-Rid\} $a>$, that for all concerned round to our self and mean well that the work is worship. And also was done to get al-Rid\}a> from Allah.

PT. Bank BNI Syariah branch of Tasikmalaya has not specification about what must do. But, must always invested be al-Ama>nah\} and al-Jama> 'ah\}. At 2016 until 2017 year in the recruitment/ revenue of the new employees that them must had been read the Al-Qur'an, it is the regulations for first interview in PT. Bank BNI Syariah branch of Tasikmalaya. Throught that rule form for valuation or measuring of alTaqwa $>$ in a subjective manner.

Every year, in PT. Bank BNI Syariah branch of Tasikmalaya have been organized the competition "Hifz,u-l-al-Qura<n (MHQ)" for ten verse's minimum. In this year, was organized that compitition for emlooyes.

That agenda will be beginning at "The Agenda of Milad PT. Bank BNI Syariah branch of Tasikmalaya every the date Juny 19".

While regarding the awards or achievments obtained by PT. BNI Syariah in applying the principle of good corporate governance is (Annual Report of PT. Bank BNI Syariah, 2016): 
(1) Trusted Company (Based on Corporate Governance Held by IICG and SWA);

(2) The Best Good Corporate Governance of Sharia Bank of Indonesia (Very Title (A) Perception Index (CGPI) Indonesia GCG Award II-2016 Event Held by Economi Review and IPMI);

(3) Rank 1 of Good Corporate Governance V-2016 (Book 2 Sharia Asset>10T Banking Endowment Indonesian V-2016 Held by Economic Review and Perbanas);

(4) The Best Quick Minded Corporate Secretary for Indonesia Syariah (Indonesia Corporate Secretary. Communicaion Award 2016 Held by Economic Review);

(5) Sustainable Finance Award 2016 (The Winner of Sharia Banking Category Held by Financial Service Authority-OJK).

Roadmap of Corporate Governance in PT. BNI Syariah is (Annual Report of PT. Bank BNI Syariah, 2016):

\begin{tabular}{|l|}
\hline \multicolumn{1}{|c|}{ 2010-2011 } \\
\hline -(Company Established) \\
Structure and \\
infrastructure runs \\
according to the \\
provisions (GCG \\
Guidelines, Guidelines \\
for Directors and Board \\
of Commissioners, \\
Character of the \\
Committees \\
\hline
\end{tabular}

\begin{tabular}{|l|}
\hline \multicolumn{1}{|c|}{ 2012-2015 } \\
\hline -Improvements of \\
Instruments and \\
mechanisms of GCG \\
on an ongoing basis, \\
the Company issued \\
sukuk, having the \\
Corporate Secretary, \\
and form a working \\
unit (PIC) supervision \\
of GCG \\
\hline
\end{tabular}

\begin{tabular}{|l|}
\hline \multicolumn{1}{|c|}{ 2016-Future } \\
\hline • External Assestment, \\
Synergy with Core \\
Integrated Committee, \\
ongoing socialization \\
through internal media \\
systems such as \\
WBS,Electronic \\
Corporate Guideline \\
(ECG), Compliance \\
Information System (CIS), \\
an update of GCG \\
guidelines \\
\hline
\end{tabular}

\section{Islamic Trick on PT. Bank BNI Syariah Branch of Tasikmalaya}

Sharia in serving customers has a religious provision that every al-Z\}uhur and $a l$ - $A s\}\} r i$ prayer, bank closed for 15 untill 20 minutes. Then when there is a customer of the bank's employees invite to pra together in the Great Masjid of Tasikmalaya, because the location of bank is very near to the mosque.

BIC (Brand Internaat Control) is regulatory board in ever bank that is tasked to report all activities on the implementation of good corporate governance and overall after the gathering of good corporate governace report in branches PT. Bank BNI Syariah. Including to the sharia bank of branch office in West Java. 


\section{CONCLUSION}

Based on the results of research and discussion we can conclude several things consistently with the hypothesis as follows:

Concept of Good corporate governance is a one of success solution the corporate for growing up and beneficially in long time and all at once appeasing the rivalry of globalization business. (1) Transparency practice is has been done is anti-gratification in carring out any job. (2) Accoutability result is had guidelines or policies that hold true for every organ, establishing the details of the duties and responsibilities ofeach organ of the company and all employees that are in line with the vision, mission, corporate values (al-Ama>nah\{- al-Jama>'ah\}-al- H\}asa>nah), and corporate strategy. (3) Responsibility result is always act with prudential principle and sticking to the applicable law, have internal information technology system namely Electronic Corporate Guideline which serves as a guide for employees regaring internal policy of PT. Bank BNI Syariah. (4) Proffesional result is have a concept al-Ama>nah\{-al$J a m a>$ ' $a h\}$ is the guide to work well and priritize the intention of worship which usually read every day in Monday and Wednesday to all member or morning breafing will be done befor 08.00 o'clock. (5) Fairness or equality result is cash ration policy or benefits cost ratio (profit sharing) for customers, consider the interest of all stakeholders based on the principle of fairness and equality (equal treatment).

According to the concept of Islamic perspective of good corporate governance's princple in PT. Bank BNI Syariah branch of Tasikmalaya is made of (1) al-Tawhi>d\} and $a l-R i d\} a>$, that for all concerned round to our self and mean well that the work is worship. The practice is: Sharia in serving customers has a religious provision that every al-Z\}uhur and $a l$ - 'As\} \}ri prayer, bank closed for 15 
minutes till same time 20 minutes. (2) Every year, BNI Syariah branch of Tasikmalaya have been organized the competition of (a) "Hifz\} $u$-l-al-Qura $<n$ (MHQ)" for ten verses's minimum (that yearwas organized that compitition for emlooyes). (b) The Agenda Milad of PT. Bank BNI Syariah branch of Tasikmalaya every date 19th of Juny. (c) Tarhib Ramdhan is Care Free Day (CFD) as the day of Ramdhan reception and celebration of the mild annualy year

\section{Reference:}

Al-Qur'an

Al-Faruqi, I. R, 1982, "al-Tawhid": Its Implications for Thought and Life", The International Institute of Islamic Thought, (Horndon: Virgina), p. 288.

Annual Report of PT. Bank BNI Syariah 2016

Berle, A and Means, G, “The Modern Corporation and Private Property”, (New York: Macmillian, 1932), p. 281.

Chapra, M. U, 1992, "Islam and The Economic Challenge", The Islamic Foundation, (Leicester:), p. 202.

Choudhur, Masadul Alam and Haque, M. 2006, Ziaul, Corporate Governance in Islamic Perspective, (Corporate Governance Jurnal), p. 91.

Daniri, Mas Ahmad, 2005, “Good Corporate Governance: Konsep dan Penerapanna di Indonesia”, (Ray, Indonesia: Jakarta), p. 9.

European Central Bank, “Annual Report 2004” in Frankfurt, 2005, p. 22.

Frank, J. and Mayer, C, 2004, "Corporate Ownership and Control in the UK, Germany and France", Stern, M. Joel and Chew, H. Donald, Jr, "The Revolution in Corporate Finance, 4th edition, (United Kingdom: Balckwell Publishing,), p 280.

Lovette, William A, 1997, "Banking and Financial Institution Law”, (USA; West Publishing, Co.), p.1 copy a pertion from Nasution, Bismar, 2007, "Hukum Kegiatan Ekonomi”, (Bandung, Books Terrace and Library), p. 152.

Mauqorrobin, Masyudi, 2017, "Fikih Tata Kelola Organisasi Laba: Sebuah Pengantar", http://tarjih.muhammadiyah.or.id/artikel-fikih-tata-kelola-organisasi-labadetail-186.html, accessible on March, 28.

Mesnooh, 2002, and Salacuse, 2003, views it as a code aiming at greater managerial transparency, responsibility and shareholder equality. Another board definition regard it as an institutional framework in which the intgrity of the transaction is decided. It encompasses not only the iternal structure of corporation but also external environtment including capital and labor markets, bankruptcy systems and governmental compitition policies.

Pedoman Umum Good Corporate Governance Indonesia. 2006, Komite Nasional Kebijakan Governance (KNKG), 2012, p. 3.

Prastowo, Andi, “Memahami Metode-Metode Penelitian”, Third Edition (Jakarta: ArRuzz Media), p. 280. 
Schieffer, dkk, (2008), "Corporate Governance: Impulses from the Middle East", Transition Studies Review, (Vol. 15, Issue 2), p. 335.

Shleifer, A. and Vishny, R, 1997, A Survey of Corporate Governance, "Journal of Finance”, edition 52), p. 737-783 in Cadhbury Report (1992). Shleifer and Vishny, explained state that it deals with the ways in which suppliers of finance to corporations assure themselves of getting a return on their investment. explains corporate governance as the system by which copanies are directed andcotrolled.

Sutedi, Adrian, 2010, “Good Corporate Governance”, (Jakarta: Sinar Grafika), p. 41. The Result of Interview in PT. Bank BNI Syariah branch of Tasikmalaya with Mr.

Alvi M. Dwi SP (Pjs. BOH), at April 28, 2017, at $05.00 \mathrm{pm}$.

Tjager, I Nyoman, et. all, 2003, "Corporate Governance: Tantangan dan Kesempatan bagi Komunitas Bisnis Indonesia”, (Jakarta: Komite Nasional Kebijakan Governance (KNKG)), p. 24.

Tuti, Rastuti, 2015, “Seluk Beluk Perusahaan dan Hukum Perusahaan”, (Bandung:

PT. Refika Aditama), p. 136

http://rismarhaesa15.wordpress.com.

https://www.encycogov.com, Financial Times, 21 Juni 1999, have been taken from "The Encyclopedia of Corporate Governance, 11 Juni 2001, p. 1, in the article at title "What Corporate Governance" copy a portion fro Chapra, M. Umer \& Ahmed, Habi, p. 18.

http://www.bnisyariah.com. $\quad$ https://yuokysurinda.wordpress.com/2016/11/20/definisigratifikasi 